\title{
Autoimmune Diabetes and Thyroiditis Complicating Treatment with Nivolumab
}

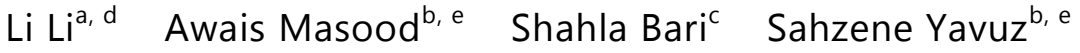 \\ Alan B. Grosbach ${ }^{a, d}$ \\ aDivision of Hematology and Oncology, Department of Medicine, University of Florida, \\ Gainesville, FL, USA; ${ }^{b}$ Division of Endocrinology, Diabetes and Metabolism, Department of \\ Medicine, University of Florida, Gainesville, FL, USA; ${ }^{C}$ Department of Medicine, University \\ of Florida, Gainesville, FL, USA; ${ }^{d}$ Division of Hematology and Oncology, Malcom Randall \\ VA Medical Center, Gainesville, FL, USA; ${ }^{\mathrm{e}}$ Division of Endocrinology, Malcom Randall VA \\ Medical Center, Gainesville, FL, USA
}

\section{Keywords}

PD-1 inhibitor · Nivolumab · Autoimmune diabetes

\begin{abstract}
Programmed cell death-1 (PD-1) ligand inhibitors have gained popularity in the treatment of advanced non-small-cell lung cancer. The immune system is regulated by stimulatory and inhibitory signaling and aims to achieve the balance between activation and inhibition. Treatment with immune checkpoint inhibitors enhances immune response, but is also known to diminish immune tolerance and increase autoimmune toxicity. Here we present a case of a patient with advanced squamous cell lung cancer who developed type I diabetes and thyroiditis after treatment with PD-1 checkpoint inhibitor nivolumab. The presence of autoimmune diabetes mellitus and thyroiditis were confirmed by markedly elevated titers of the glutamic acid decarboxylase autoantibody and thyroid peroxidase antibody, respectively.
\end{abstract}




\section{Case Reports in Oncology}

Case Rep Oncol 2017;10:230-234

DOI: $10.1159 / 000456540$

(c)

2017 The Author(s). Published by S. Karger AG, Base www.karger.com/cro

Li et al.: Autoimmune Diabetes and Thyroiditis Complicating Treatment with Nivolumab

This report serves to heighten awareness of potential autoimmune toxicities related to antiPD-1 therapy, especially as these toxicities are manageable if identified in a timely manner.

(C) 2017 The Author(s)

Published by S. Karger AG, Basel

\section{Background}

The programmed cell death-1 (PD-1) inhibitor nivolumab became the standard treatment after the failure of systemic chemotherapy in both advanced squamous and nonsquamous-cell carcinoma of the lung [1-3]. The toxicity profile of PD-1 inhibitors is distinctive from cytotoxic chemotherapy and includes skin rash, colitis, autoimmune hepatitis, pneumonitis, and endocrinopathies of the pituitary, thyroid, and adrenal glands. Autoimmune diabetes was reported in a patient with metastatic melanoma treated with pembrolizumab [4]. In this case a patient with advanced squamous cell lung cancer was treated with nivolumab and developed autoimmune diabetes and thyroiditis.

\section{Case Presentation}

A 63-year-old African-American male, with no prior history of diabetes mellitus, presented with cough and dyspnea. CT scan showed a 5-cm right hilar mass and bulky mediastinal adenopathy. Stage IIIA squamous cell carcinoma of the lung was diagnosed by transbronchial biopsy, and concurrent chemoradiation was initiated with carboplatin and paclitaxel. Seven months after completion of treatment, the patient developed right lower lobe collapse and underwent bronchoscopy which demonstrated a large, completely obstructing endobronchial lesion in the right upper lobe. Biopsy confirmed recurrent squamous cell carcinoma. He received 3 cycles of intratumoral injection with cisplatin and achieved a good response. Unfortunately, 4 months later he experienced further disease progression, with a new enhancing pleural nodule and chest wall involvement on chest CT. Nivolumab therapy was initiated based on its survival benefit and potential for durable response [2]. Twenty-seven days after the first nivolumab dose, he presented to the emergency department with palpitations and fatigue. Blood glucose on admission was $592 \mathrm{mg} / \mathrm{dL}$. He also has ketonemia and elevated anion gap. He was diagnosed with diabetic ketoacidosis (DKA) and treated intravenously with insulin and fluids. He responded well to management of DKA, and a standard insulin regimen was established. Further investigation demonstrated a markedly positive anti-glutamic acid decarboxylase (GAD) antibody and thyroid peroxidase (TPO) antibody (Table 1). Initial TSH was normal, but the TPO antibody was positive and he developed primary hypothyroidism 3 months later after the initiation of immunotherapy.

A third dose of nivolumab was administered, and his new-onset type 1 diabetes mellitus was managed with multiple daily insulin injections. Hypothyroidism was treated with levothyroxine. Over the next 3 months his diabetes remained difficult to control, requiring hospitalization for repeated episodes of DKA. Nivolumab treatment was stopped due to recurrent DKA. A PET scan performed during one of the admissions demonstrated widespread meta- 


\section{Case Reports in Oncology}

static disease, and the patient was enrolled in a hospice. His status deteriorated, and he expired 5 months after starting nivolumab.

\section{Discussion}

Immune checkpoint inhibitors including ipilimumab, nivolumab, pembrolizumab, and atezolizumab are FDA approved for the treatment of advanced malignancies, including nonsmall-cell lung cancer (NSCLC), melanoma, renal cell carcinoma, and urothelial carcinoma. Nivolumab was recently approved for relapsed/refractory classic Hodgkin lymphoma. Additional applications are under investigation [5]. Checkpoint inhibitors have demonstrated progression or overall survival benefits when compared to traditional chemotherapy. More importantly, they produce a durable response which leads to prolonged overall survival.

T-cell activation is regulated by a dynamic interplay and balance of positive and negative signaling pathways. PD-1 is expressed on activated T cells and, upon interaction with its ligands PD-L1 and PD-L2, mediates inhibitory signaling via recruited cytoplasmic tyrosine phosphatase SHP-2 to immunoreceptor tyrosine-based switch motif, rather than immunoreceptor tyrosine-based inhibitory motif, which is more commonly associated with inhibitory signaling. This results in the negative regulation of immune response through decreased production of IL-2 [6, 7]. PD-L1 is widely expressed on tumor cells and other immune cells. Tumor cells can evade host immune surveillance by downregulating cytotoxic $\mathrm{T}$-cell signaling through the upregulation of PD-L1 expression. PD-1 inhibitor interrupts the inhibitory signaling and enhances T-cell immunity; however, it may also cause impaired immune tolerance and autoimmune toxicities.

Our patient had no prior diagnosis of diabetes mellitus or thyroid disease, but presented with DKA 27 days after the initiation of nivolumab. GAD antibody titer was 26.6, which was markedly elevated (Table 1). He also had evidence of thyroid autoimmunity with positive TPO antibody. Even though initially euthyroid, he developed overt primary hypothyroidism 3 months after the initiation of anti-PD-1 immunotherapy. The patient had no clinical signs or symptoms of adrenal insufficiency or hypophysitis.

In a preclinical model, PD-1-deficient (PD-1-/-) mice develop different autoimmune diseases depending on genetic background, which indicates that PD-1 plays a role of inhibitory signaling in immune response. The PD-1/- mice on the C57BL/6 background develop lupuslike glomerulonephritis, whereas those with the BALB/c background develop a phenotype of anti-cardiac troponin I autoantibody-mediated dilated cardiomyopathy [8, 9]. The nonobese diabetic (NOD) mouse is a model of type I diabetes. NOD-Pdcd1-/- mice exhibit ac celeration of early-onset type I diabetes compared with NOD mice with $100 \%$ penetration $[10,11]$.

Consistent with the preclinical model, autoimmune diabetes has been reported in patients treated with PD-1 inhibitors. Martin-Liberal et al. [4] have reported a patient with metastatic melanoma who developed diabetes after 3 cycles of pembrolizumab. Autoimmune diabetes was diagnosed with positive GAD antibody and anti-insulin IgG. Human leucocyte antigen (HLA) typing in this patient showed HLA-A2, DR4, and DQ8, consistent with increased risk of type I diabetes in children. This patient was continued on pembrolizumab with no increased insulin requirement. Hughes et al. [12] reported 4 cases of type I diabetes 
in patients treated with nivolumab for NSCLC, SCLC, melanoma, and renal cell carcinoma, and 1 case in a patient treated with pembrolizumab for melanoma. The onset of DM ranges from 1 week to 5 months. HLA typing demonstrated both A2.1+ and DR4+ in 3 patients; A2.1+ or DR4+ alone was found in the other 2 patients. The patient with NSCLC developed DKA in less than 1 month after nivolumab, whereas our patient developed type I diabetes after only 2 doses of nivolumab.

\section{Conclusion}

Nivolumab therapy demands vigilance for the possible development of serious autoimmune complications. Our case illustrates the risk of these complications both during and subsequent to nivolumab therapy.

\section{Statement of Ethics}

The authors have no ethical conflicts to disclose.

\section{Disclosure Statement}

The authors declare that they have no conflicts of interest.

\section{References}

1 Borghaei H, Paz-Ares L, Horn L, Spigel DR, Steins M, Ready NE, et al: Nivolumab versus docetaxel in advanced nonsquamous non-small-cell lung cancer. N Engl J Med 2015;373:1627-1639.

-2 Brahmer J, Reckamp KL, Baas P, Crino L, Eberhardt WE, Poddubskaya E, et al: Nivolumab versus docetaxel in advanced squamous-cell non-small-cell lung cancer. N Engl J Med 2015;373:123-135.

3 Garon EB, Rizvi NA, Hui R, Leighl N, Balmanoukian AS, Eder JP, et al: Pembrolizumab for the treatment of non-small-cell lung cancer. N Engl J Med 2015;372:2018-2028.

4 Martin-Liberal J, Furness AJ, Joshi K, Peggs KS, Quezada SA, Larkin J: Anti-programmed cell death-1 therapy and insulin-dependent diabetes: a case report. Cancer Immunol Immunother 2015;64:765767.

5 Whiteside TL, Demaria S, Rodriguez-Ruiz ME, Zarour HM, Melero I: Emerging opportunities and challenges in cancer immunotherapy. Clin Cancer Res 2016;22:1845-1855.

6 Ohaegbulam KC, Assal A, Lazar-Molnar E, Yao Y, Zang X: Human cancer immunotherapy with antibodies to the PD-1 and PD-L1 pathway. Trends Mol Med 2015;21:24-33.

7 Khoury SJ, Sayegh MH: The roles of the new negative T cell costimulatory pathways in regulating autoimmunity. Immunity 2004;20:529-538.

8 Nishimura H, Nose M, Hiai H, Minato N, Honjo T: Development of lupus-like autoimmune diseases by disruption of the PD-1 gene encoding an ITIM motif-carrying immunoreceptor. Immunity 1999;11:141-151.

-9 Nishimura H, Okazaki T, Tanaka Y, Nakatani K, Hara M, Matsumori A, et al: Autoimmune dilated cardiomyopathy in PD-1 receptor-deficient mice. Science 2001;291:319-322.

10 Wang J, Yoshida T, Nakaki F, Hiai H, Okazaki T, Honjo T: Establishment of NOD-Pdcd1-/- mice as an efficient animal model of type I diabetes. Proc Natl Acad Sci USA 2005;102:11823-11828. 


\section{Case Reports in Oncology}

\begin{tabular}{l|l}
\hline Case Rep Oncol 2017;10:230-234 \\
\hline DOI: $10.1159 / 000456540$ & $\begin{array}{l}\text { C } 2017 \text { The Author(s). Published by S. Karger AG, Basel } \\
\text { www.karger.com/cro }\end{array}$ \\
\hline
\end{tabular}

Li et al.: Autoimmune Diabetes and Thyroiditis Complicating Treatment with Nivolumab

11 Okazaki T, Chikuma S, Iwai Y, Fagarasan S, Honjo T: A rheostat for immune responses: the unique properties of PD-1 and their advantages for clinical application. Nat Immunol 2013;14:1212-1218.

-12 Hughes J, Vudattu N, Sznol M, Gettinger S, Kluger H, Lupsa B, et al: Precipitation of autoimmune diabetes with anti-PD-1 immunotherapy. Diabetes Care 2015;38:e55-e57.

Table 1. Laboratory values

\begin{tabular}{lllll}
\hline & $\begin{array}{l}\text { Reference } \\
\text { range }\end{array}$ & $\begin{array}{l}\text { Before } \\
\text { treatment }\end{array}$ & $\begin{array}{l}\text { After } \\
\text { nivolumab } \\
(27 \text { days) }\end{array}$ & $\begin{array}{l}\text { After } \\
\text { nivolumab } \\
\text { (about 3 months) }\end{array}$ \\
\hline $\mathrm{HbA}_{1 \mathrm{c}}$ & $<6.4 \%$ & unavailable ${ }^{1}$ & $7.2 \%$ & $9.2 \%$ \\
$\mathrm{TSH}$ & $0.27-4.2 \mathrm{IU} / \mathrm{mL}$ & 1.3 & 1.9 & 35.56 \\
Anti-GAD antibody & $<1 \mathrm{U} / \mathrm{mL}$ & unavailable & 26.6 & unavailable \\
Anti-TPO antibody & $<9 \mathrm{IU} / \mathrm{mL}$ & unavailable & 17 & unavailable \\
\hline
\end{tabular}

${ }^{1}$ Fasting blood glucose $91 \mathrm{mg} / \mathrm{dL}$ at baseline. 